\title{
The Internship Practicum and Guidebooks in Teacher Training: A Social Studies Teaching Model
}

\author{
Nadire Emel Akhan \\ Burcu Kaymak \\ Akdeniz University, Turkey
}

Doi:10.19044/ejes.v7no3a6 URL:http://dx.doi.org/10.19044/ejes.v7no3a6

\begin{abstract}
The purpose of this research is to determine the opinions of academicians teaching the internship practicum course at different universities and to examine the guidebooks used by universities according to set criteria. The sample consists of 17 academicians at 17 state universities. The data were collected using the qualitative research method and analysed with descriptive analysis. The results of the research have indicated that the academicians do not follow the pre-service teachers weekly and evaluate them according to the internship files and the opinions of their mentors. It has been also determined that the guidebooks used in the internship practicum are not field-specific.
\end{abstract}

Keywords: School experience, teaching practice, guidebook, academician.

\section{Introduction}

As an occupation that implements teaching and education, the teaching profession has priority among services of education and training. The teaching practice education received by pre-service teachers is an important component of pre-service education, for in pre-service, student teachers obtain an opportunity to put into practice in real classroom environments what they have learned, thereby applying their theoretical knowledge (Akyüz, 2001; Mtika, 2008; Nonis \& Jernice, 2011; Aglazor, 2017; Çelik, 2008; Carpenter \& Balance, 2007; Allen \& Wright, 2014; Alemdağ \& Özdemir Şimşek, 2017; Eryaman, 2007).

When information about the significance of teaching practice at different universities across the world is examined, it is seen that similar importance is attached to it. According to National University Commission (NUC, 2007) and Benchmark National Commission for Colleges of Education (NCCE, 2015), the internship experience in teaching provides pre-service teachers with the opportunity to apply what they have learned in real life, to discover their strengths and weaknesses, thereby enabling them to acquire 
professional skills, competence and experience, and to benefit from the education they have received by taking a favourable attitude towards the teaching profession. At the same time, the feedbacks, responsibilities, acquisition of different roles, and cooperation with academicians and teachers provided by the teaching practice promote pre-service teachers' professional competence and help them socialize (cited in Aglazor, 2017; Assimonye, 2014; Riedler \& Eryaman, 2016; Clarke et al., 2014).

When the significance attached to teaching practicum in Turkey is examined, it is seen that expectations from the teaching practicum are expressed in similar terms in the general objectives of MNE: "It regulates the procedures and principles regarding the practice activities by enabling preservice teachers to acquire the competence to better prepare for the teaching profession, and use the general knowledge, as well as information, skills, attitudes and habits they have acquired with regard to their special fields of education and the teaching profession in a real education and training environment" (MNE, 2018, p. 1).

Established by the 1982 Constitution in Turkey, the Council of Higher Education (CHE) in Turkey became a center for planning and management when education institutions (2 and 3-year teacher training schools) were integrated into universities. In order to reform this program, a "Pre-Service Teacher Training Project" was implemented in 1998 and 1999 in cooperation with CHE and the World Bank. New departments such as social studies, mathematics, science, Turkish and form teaching were established as a result of this reform. In spite of all the regulations made, it has been observed that universities and the Ministry of National Education act independently of each other. Although internship programs were offered to preservice teachers with an agreement between these two institutions, these internship programs could not go beyond being regarded as ordinary courses and caused school experience and teaching practice classes to be considered insignificant and inefficient by academicians, pre-service teachers and teachers (Akdemir, 2013; YÖK, 1998; Atanur Başkan et al., 2006; Şişman \& Acat, 2003).

It should be noted that the guidance provided by both teachers and academicians has become an important part of the teaching practice, for preservice teachers perform their internship education together with experienced and knowledgeable teachers and academicians during the internship programs. However, faculty stakeholders and the cooperating school where the internship education is held also have an important part to play in organizing an efficient internship program for pre-service teachers. The availability of participating schools for internship, the cost of the program and availability of qualified teachers/mentors are some of these roles. Considering that each stakeholder is important in its own right, presence of a clear, understandable and well-prepared internship guidebook where tasks and responsibilities have 
been properly laid out is the cornerstone of an internship program. Essential points such as assessment procedures and responsibilities for academicians and the others involved, the number of students under their supervision and their cooperation with the teacher at the internship school should be stated clearly; likewise, information about what practices should be implemented in what order during the process should also be stated clearly. In this way, assessments made during the internship practice will eliminate certain problems and thus render the practice better equipped (Schwille, 2008; Cain, 2009; Hudson, 2013; Izadinia, 2016; Maynard, 2000; Hobson, 2002; Jones, 2001; Ekizer, 2006; Zeichner, 2002; Aglazor, 2017; Ekpo, 2019).

The internship guidebooks should be prepared to serve as a functional tool for the purposes specified for each teaching practice unit. Internship guidebooks should play a significant role in the internship practice by systematizing the collaboration between mentors and academicians and allow for an effective evaluation of pre-service teachers by providing constant guidance to them, for while according to an academician or a teacher what an intern can investigate during the internship is clear, it may become more complicated and inextricable for pre-service teachers doing their internship (Assimonye, 2014; Kessels \& Korthagen, 1996).

When the relevant literature is examined, it is seen that there is ample research investigating school experience and teaching practicum (Riedler \& Eryaman, 2016; Clarke et al., 2014; Akdemir, 2013; Izadinia, 2016; Maynard, 2000; Hobson, 2002; Jones, 2001; Ekizer, 2006;Y1lmaz \& Kab, 2013; Seçer et al., 2010; Yılmaz, 2019; Hurioğlu, 2016; Aytaçl1, 2012; Göktaş \& Şad, 2014; Özk1lıç et al., 2008; Baştürk, 2009; Oğuz \& Avc1, 2014; Sünkür Çakmak, 2019), but the number of studies aimed at assessing feasibility of internship guidebooks, which serve as useful and important guides, their suitability for the sample and the department as well as their functionality is limited (Şahin \& Özk1liç, 2005; Asmimonye, 2014; Kessels \& Korthagen, 1996; Ergüneş, 2005). It is also observed that the aforementioned research is limited in terms of generalizability and that they attempt to determine the state of the field only through a single university. Therefore, interviews were made with academicians serving as advisers at school experience and teaching practice at 17 universities in Turkey and topics such as what they did during the internship practices, whether or not they followed a guidebook and functionality of those guidebooks were tried to be determined from the perspective of academicians. Moreover, the official guidebooks used by these universities were examined and an attempt was made to determine issues such as functionality of these guidebooks, their fitness for purpose and their currency. 


\section{Method}

Basic qualitative research method was used in this study. Basic qualitative studies focus on how individuals construct realities/facts as a consequence of their interaction with their social worlds. Therefore, in basic qualitative research, researchers are concerned with what kind of meaning people attach to experiences, how they construct their worlds and interpret their lives (Merriam, 2018).

\section{The Sample}

The sample of the study consists of academicians teaching the school experience and teaching practice course at 17 state universities in Turkey. An attempt was made to increase reliability of the study by reaching state universities in different regions of Turkey in determining the sample of the study. Participation in the study was on a voluntary basis and it consisted of 8 female and 9 male academicians employed at 17 universities, which were deemed to be easily accessible. The school experience and teaching practice guidebooks investigated in the study, on the other hand, were requested from the academicians working at the said universities. The guidebooks that could not be obtained via academicians were reached through the websites of the universities.

\section{Data Collection and Analysis}

The data of the study were collected by e-mail. A questionnaire consisting of five semi-structured open-ended questions was administered to the participants. E-mail helps conduct in-depth interviews without the need for synchronization and one can engage in multiple online e-mail exchanges (Creswell, 2018; Meho, 2006; Kazmer \& Xie, 2008). As for the measurement tool of the study, first relevant literature was reviewed and expert opinions were taken. Then, expert opinions were taken again by the researchers about the open-ended questions in accordance with the purpose of the study and finally 5 questions were determined. These 5 questions had their own subdimensions. This measurement tool was administered to 8 academicians not included in the sample. After these academicians checked items such as the scope of the topic, comprehensibility and manner of expression and provided positive feedback with regard to them, the questionnaire form was accepted as the measurement tool. An introduction was added to the beginning of this questionnaire form, specifying the purpose and content of the study. It was guaranteed that no information would be revealed about the participating university and the academicians. Then, a list was prepared of the e-mails of the academicians at the social studies teaching departments of the education faculties of universities. The questionnaire forms were sent to the e-mails list, which had been prepared taking into account almost all geographical regions 
of Turkey. It was ensured that the forms were sent to 2 academicians from each university. It was guaranteed in the e-mails sent that participation was on a voluntary basis and that information about identity and institution would be kept confidential. There were responses to 24 of the e-mails sent. 17 of these e-mail responses were accepted as study data whereas the remaining 7 data were excluded from the study on the grounds that they were incomplete, contained short answers in the form of yes and no, or no explanations were made concerning the answers.

Other sources of data used in the study are teaching practice guidebooks. These guidebooks were requested from the academicians who had been contacted via e-mail. These academicians were asked to send the guidebooks they had been using and 12 of these academicians sent the guidebooks they used via e-mail again. The other 5 academicians, on the other hand, did not send their guidebooks, stating that they did not have them in computer environment. These 5 guides were obtained from the internet page of the relevant university and since they were based on $\mathrm{CHE}$ and MNE, they were used directly for purposes of the study.

The data obtained as a result of the correspondence with the academics and the documents reached were examined and analysed descriptively. In detailed descriptive analysis, authors systematically interpret what they see, providing a natural environment in the context of identifying a person's location or event (Creswell, 2018). The document analysis technique was used in the examination of the guidebooks of the universities. The document review also includes the process of obtaining permission for their use after determining the materials in remote locations (Creswell, 2018).

The data obtained as a result of the study were tested for validity and reliability but this was undertaken by two experts in the field in order to increase the validity and reliability of the study. According to calculations made using Miles and Huberman's formula of (1994) R (Reliability) $=[\mathrm{Na}$ (Agreement 117) / Na (Agreement 117) + Nd (Disagreement 12)] x 100, reliability was at the level of $90 \%$ and the study was proven to be reliable. Moreover, the findings of the study were supported through direct quotations from the participants (U1: University 1, U5: University 5 etc.).

\section{Findings}

\section{Findings about the academicians' views regarding whether there is a directive determined by the faculty concerning school experience and if there is one, whether or not they are following it}

When the academicians in the sample were asked about their opinions regarding whether there was a directive determined by the relevant faculty about school experience, 9 of them answered yes, 5 responded no and 3 stated that they used the guidebook after some revision. When asked whether they 
followed the guidebook found in their faculty, 10 of them said they used the guidebook prepared by the faculty, 1 by CHE, 1 by MNE and 1 said they used a blend of $\mathrm{CHE}$ and Faculty guidebooks. Some of the responses given by the academicians are as follows: "There is a directive determined by our faculty. I am trying to follow this directive" (U 7), "Yes, there is. I don't follow much. It has become a routine" (U 8), "No, there isn't. We follow the old directive by CHE and the World Bank" (U 13), "Yes, there is. I use only practicum headlines as models. I don't follow the directive" (U 17), "Yes, there is. Though we comply with the overall rules, we usually stretch those rules for school experience within the school's own conditions" (U 12), "There is no directive. Therefore, I do not follow one" (U 4).

\section{1.a. Findings about academicians' opinions concerning preparation before class and what they do in this regard}

When asked about their opinions as to whether they made preparations before the school experience class, 9 of the academicians in the sample answered yes whereas 7 answered no. When the academicians were asked about their opinions concerning what they did in this course, it transpired that 6 talked to the school administration/mentor in charge, 2 conducted theoretical classes, 1 examined directives of different faculties, 1 cooperated with the faculty and $\mathrm{CHE}, 1$ held meetings with the students and 1 collected information about the school. Some of the answers given by the academicians are as follows:

"I examine directives of different schools. I create my own syllabus by following the instructions of the faculty and directives prepared in cooperation with CHE and the faculty" (U 1), No, I don't" (U 4). No, I don't, but in the years when I first began to teach this course, I made additions to and eliminations from the activities in the directive, for there could be activities that could not be performed due to the physical conditions of the school or other circumstances. (U11). At the beginning of the semester, I go to internship schools and I meet school administrators and mentors at the school. I take a look at the directive before the class so that I can give information to students (U 10).

\section{1.b. Findings about the opinions of the academicians concerning whether they follow their students weekly, and if their response is positive, what they do in this regard}

When the academicians in the sample were asked about whether they supervised their students on a weekly basis, 9 responded no and 8 responded yes. 7 of those who responded yes stated that they exchanged ideas, 6 received feedback regarding what was done, 2 introduced/evaluated the process, 1 assessed the reports, 1 received feedback via messaging and introduction to 
the school/teacher and 1 received information about attendance. Responses of some of the academicians are as follows:

"We meet at least once every week and evaluate the reports of the preservice teachers concerning the activities of the relevant week" (U 14), I conduct a follow-up not every week but once a month to get information about the status of the activities the students have performed (U 11), "No, I don't. I don't follow them every week. I make a general assessment in the last week" (U4), "We communicate via whatsapp every week for sure. I answer their questions about the work they do. They may ask about points in the directive that have not been quite understood" (U 13), "It is not possible for me to follow every week due to my tight schedule" (U 7).

\section{1.c. Findings about the views of the academicians concerning how they make the final general evaluation of the students in the school experienc}

When the academicians in the sample were asked about their opinions regarding how they conducted the final general evaluation of the students in the school experience, it was found that 11 evaluated via the files the students prepared, 10 via assessments made by the mentors, 7 on the basis of their attendance, 2 on the basis of performance, 1 based on an assessment scale prepared by himself/herself, 1 from the way they taught classes, 1 in terms of professional qualities of social studies and 1 as a result of observations s/he made. Some of the responses given by the academics are as follows:

"It is predominantly performance-based. Participation in the practice and assessment of the mentors are also very important of course" (U 5), "I make my evaluation according to the internship files, notably views of the mentors at the internship school and observation notes" (U 13), "I make my evaluation according to a grading scale which I have created for the files the students have prepared and a different grading scale which I have prepared for the evaluation of the mentor" (U1), "I examine their files. I evaluate them by checking their attendance and sometimes by contacting their mentors (U 8).

In general, I consider my students to be competent. Our students prepare a report for each week during the 14-week program (one day of the student, one day of the teacher, preparing examination questions etc.). I evaluate my students according to these reports (U 15). 
2. Findings about the academicians' views regarding whether there is a directive prepared by the relevant faculty with respect to the teaching practice and if there is one, whether they follow this guidebook or not

When the academicians in the sample were asked about their opinions concerning whether there was a directive determined by the faculty or not, 13 responded yes while 4 responded no. When it was asked whether they followed the guidebook in the faculty or not, 7 it was found that 7 followed the directive of the faculty, 2 followed the directive of the Ministry of National Education, whereas 2 said there was a directive but they did not follow it and 1 stated that s/he acted in line with their own opinion every week. Some of the responses given by the academicians are as follows:

"No, there isn't. I follow the old directive prepared by CHE and World Bank" (M13), "Our faculty demands that we follow the directive requested by MNE. I score my students by going to the school every three months and listening to my students" (T15).

2.a Findings about the academicians' opinions concerning whether they make preparations before the teaching practice and if they do, what kind of preparations they make

When the academicians in the sample were asked whether or not they made preparations before the teaching practicum, 10 of them responded yes while 4 responded no. When the academicians were asked what kind of preparations they made before the practicum, it was found that 4 of them checked the plans every week, 4 worked in collaboration with the school, 4 held seminars with the students, 3 made a plan after examining the latest regulations and 1 held interviews with the students every week. Some of the responses given by the academicians are as follows:

"I give the weekly plans to be implemented in the practicum and then check" (U 2). Yes, I do. First of all, I contact the administrator and guidance and counselling teacher of the school where my student group will go and we decide on the day we will go to the school to meet each other. I prepare beforehand the documents that the students will be required to complete during the practicum. (U6)

I hold a meeting like a seminar on the importance of the course, the teaching profession, taking notes during the practice, and going to the school in a manner suited to the requirements of the teaching profession. Also, I provide detailed information about what they are supposed to do during the school experience. (U 7) 


\section{2.b. Findings about the academicians' opinions concerning whether they follow the students every week in the teaching practicum or not and if yes, what they do}

When the academicians in the sample were asked about whether they supervised the students every week during the teaching practicum or not, 7 of them responded yes and 4 responded no. When they were asked how they supervised the students, it was found that 4 held seminars with them every week, 1 gave feedback to the students every week, 1 exchanged views with the mentor at the beginning of the semester, while 1 provided feedback via social media. Some of the responses given by the academicians are as follows:

"We make a point of corresponding via whatsapp every week for sure. I answer questions about their work. We talk online about class observations and the presentations they will make" (U 13), "I go to listen to and watch the students once every semester. I ask them to submit to me their files. I do not check them every week, but since they come to theoretical classes with their files ready, I am informed of their files" (U 10), "I go to the practice school every week and meet the mentors and my students. I give feedback to the students I have observed regarding their classes" (U 1).

\section{2.c. Findings about the academicians' views concerning whether or not they make observations at the students' schools during the teaching practice, and if yes, what kind of things they do}

When the academicians in the sample were asked about their opinions concerning whether or not they made observations at the students' schools, they stated that they made observations. On the other hand, when they were asked what they did in their observations during the teaching practice, 9 responded "other", 8 "my overall opinion", 4 "the guide", and 4 "my own conclusions". Some of the responses given by the academicians are as follows:

"I make my evaluations using the class observation forms included in our guide book" (U 14), "By listening and saying my opinion. I score my students by listening. I have my own criteria of 15 items. I apply the same criteria here as I do in my special teaching methods course" (U 15), "I observe my students. I make general evaluations, making use of MNE's pre-service teacher assessment criteria. I have not been fully able to use them effectively but active use of these criteria in each observation will lead to healthier evaluations" (U 1).

\section{2.d. Findings about the academicians' views concerning how the students' final general evaluations are made in the teaching practice}

When their views were asked about how they evaluated the students in the practicum, it was found that 11 of the academicians evaluated according to the opinions of the mentor, 6 as a result of portfolio assessments, 4 
according to the course system created by MNE, 2 according to their own evaluation system, 2 according to student attendance and 1 according to students' enthusiasm. Some of the responses given by the academicians are as follows:

"I make a general evaluation on the basis of the mentors' opinions, my observation notes, the way the files were prepared, the students' attendance to classes, and their participation in the theoretical classes" (U9), "I make my evaluations by taking the opinion of the mentor at the practice school" (U7), "By taking the average of mentor assessment, class observation forms and my evaluation of the files they have prepared." (U14), "I base my assessment on the score obtained from the evaluations of the mentor and the academician, drawing on the evaluation system created by MNE" (U10).

\section{Findings about the academicians' opinions and suggestions concerning how to make the school experience and teaching practice course more efficient}

When the academicians in the sample were asked about their opinions regarding how to make the school experience and teaching practice course more effective, 6 referred to assigning students to counsellors specialized in their fields, 5 changing the semester when the internship practice was performed, 5 failure in ensuring cooperation between MNE and academician, 3 paying attention to feasibility, 3 importance attached to attendance, 2 the issue of conducting classes, 1 adding KPSS (public personnel selection examination) score to internship evaluation and 1 providing effective mentorship. Some of the responses given by the academicians are as follows: "When determining the criteria for the school experience and practicum classes, it should be ensured that they are realistic and feasible" (U 6).

It should not be implemented in the present academic semester; pre-service teachers should not be bothered with other courses. Like internships at other faculties, for example. A whole semester should be reserved for this course only, because the academicians' schedules are not suitable to supervise and watch/listen to the students constantly. (U 4)

...The changes MNE has been implementing in recent years within the scope of teaching practice and the announcements about them usually remain within the confines of MNE. For example, I learn the changes made to the evaluation system from the mentors. They, in turn, wait for guidance from me but I don't know about them in the first place. (U 1) 


\section{Findings about the examination of the school experience and teaching guidebooks in terms of their field-specific nature and the masthead}

When the school experience and teaching practice guidebooks were examined, it was found that none of the 17 universities had a guidebook unique to the field of social studies teaching. It is seen that the existing guidebooks were created for the field of teaching in general by preparing explanations/examples for activities without making any distinction among numerical, verbal, foreign language or psychomotor fields. When the masthead information for these guidebooks were examined, it was found that 7 of the universities used a guidebook prepared according to a decree law passed in 2011 in line with MNE Law no. 1973, 7 used a guidebook prepared within the scope of CHE/World Bank National Education Development Project Pre-Service Teacher Education dated 1998, 2 used a guidebook prepared in cooperation with $\mathrm{MNE}$ and $\mathrm{CHE}$, and 1 used a guidebook prepared in cooperation with MNE and the faculty.

5. Findings about determination of duties and responsibilities of stakeholders (faculty administration, faculty practice coordinator, department practice coordinator, practice instructor, pre-service teacher, directorate of national education etc.) in the school experience and teaching practice guidebook

When the school experience and teaching practice guidebooks are examined, it is seen that the guidebooks of 10 universities out of 17 list the duties and responsibilities of the stakeholders separately, whereas the guidebooks of 7 universities contain no information about the duties and responsibilities of the stakeholders. In the guidebooks of these 10 universities, where information is given about duties and responsibilities, some duties of education faculties are listed as "preparation and supervision of pre-service teachers, determination of academicians responsible for practicum, and organization of seminars and courses"; the duties of the faculty practice coordination office are listed as "preparation of a list of practice schools, holding meetings with mentors and academicians about possible problems, and organization of practice activities in accordance with laws and regulations"; whereas the duties and responsibilities of the department practice coordinator are listed as "informing the academicians about forms, observations and assessment criteria, and ensuring coordination between the department and the faculty".

\section{Discussion, Conclusion and Suggestions}

Based on a general evaluation of the results of this study, which aimed to determine some points such as what the academicians teaching the school experience and teaching practice course at state universities in Turkey did in 
the internship practices, whether they stuck to the guidebooks or not and the functionality and guiding quality of these guidebooks, it can be said that there were directives created by faculties for the implementation of the school experience and teaching practice course and they followed these directives. It could also be said that the academicians generally came to school experience and teaching practice classes by preparing appropriately beforehand, but they did not supervise their students every week in the school experience and teaching practice classes. It was also found that the reports prepared by students, their attendance, mentor opinions and MNE assessment criteria were used as a basis in both school experience and teaching practice classes and that academicians observed their students at internship schools and made evaluations according to their own assessment criteria. It was suggested suggested that in order to make school experience and practicum classes more efficient, experts in the field should be appointed as mentors, internship semesters should be changed, and a more solid coordination should be ensured between MNE and academicians. It was seen that none of the guidebooks used were specific to the field of social sciences and that generally guidebooks prepared by a MNE decree law and those prepared in cooperation with $\mathrm{CHE}$ and the World Bank were used. It was determined that the guidebooks used generally specified the duties and responsibilities of stakeholders.

In the examination of the sub-dimensions, first, the academicians were asked whether there was a directive determined by the relevant faculty concerning school experience and a large majority of the academicians responded that they had a directive. However, it was determined that the number of academicians who stated that they did not have a directive or used the current directive after a revision was close to the number of academicians who said they had a directive. When the state of following the current directive was asked, it was found that 10 academicians used the directive prepared by the faculty, 1 the one prepared by CHE, 1 the one prepared by MNE, 1 a blend of $\mathrm{CHE}$ and faculty guidebooks. When asked whether the relevant faculty had a directive regarding the teaching practice, a large majority of the academicians responded that it did. It was found that while a majority of those having a directive followed that guidebook, some stated that although they had a guidebook concerning internship, they followed the directive of MNE or a directive which they created according to their own criteria. Apart from this, it was seen that there were some among the academicians who, although they had a guidebook, stated that they did not use the current guide. In parallel to the findings of the present study, Güngör (2018)'s study indicates that academicians evaluated pre-service teachers according to their own personal assessment criteria during the internship program.

When asked for their opinions concerning whether they made preparations for the school experience course, it was found that 9 of the 
academicians made preparations beforehand, whereas 7 did not make any preparations. It was seen that the academicians who responded that they made preparations beforehand cited examples such as holding talks with the school administration or the mentor, conducting theoretical classes, cooperating with the mentor or the cooperating school, examining the directive, preparing materials, holding meetings and getting information about the school. When asked for their opinions regarding making preparations for the practicum, a large majority of them stated that they made preparations, citing examples such as checking the plans, cooperating with the school and organizing seminars.

When the academicians were asked whether or not they supervised their students week by week, interestingly enough, it transpired that a large majority of them did not follow on a weekly basis. The academicians who supervised on a weekly basis, on the other hand, engaged in activities such as receiving feedback, exchanging ideas and receiving information about attendance. Likewise, it was determined that the academicians did not supervise their students on a weekly basis in the teaching practice, either, and those who did engaged in activities such as receiving feedback, exchanging ideas with the mentor and organizing seminars. Unlike the findings of this study, it was determined in a study conducted by Güngör (2018) that academicians did not follow the activities on a weekly basis and the students did not generally perform all of the specified activities. Paker (2008)'s study, on the other hand focused, in parallel with the findings of our study, on giving feedback, emphasized the importance of giving feedback to pre-service teachers and suggested that feedback should be given in the right place at the right time.

When the academicians were asked how they evaluated the school experience course at the final stage, a large majority of them stated that they examined the files prepared by the students, received the mentor's opinions, checked attendance and made assessments according to criteria set by themselves. As for the teaching practice, on the other hand, a large majority stated that they made the final evaluation on the basis of the mentor's opinions, but others also stated that they made it according to criteria such as portfolio examination, the course system of MNE, their own assessment system and attendance. In parallel with the finding of the study, it was stated in Güngör (2018)'s study that evaluation was made in the teaching practice course according to attendance to classes and students' performance in the classes.

When the academicians were asked whether or not they made observations at the students' schools during the teaching practice, it was found that all of the academicians made observations and they made their evaluations during these observations according to criteria such as those criteria set by themselves, their overall opinion and the expectations specified in the 
guidebook. In order to make school experience and teaching practice classes more efficient, suggestions were made such as assigning students to specialist advisers in the field, changing internship semesters, ensuring coordination between MNE and academicians, and making attempts at feasible activities. In parallel with the findings of the present study, Öztürk, (2001 retold by Büyükduman, no date), Kılıç (2004), Paker (2008), Görgen et al., (2012) stated in their respective studies that not assigning students to specialist advisers in the field could lead to problems and pedagogical course training should be provided to academicians and teachers, arguing that advisers lacking in internship experience will not be competent in terms of quality and quantity. As far as changing the internship semesters was concerned, it was found in a study by Ünlü Saratlı (2007) that school experience course should be given not only in the senior year but also in the first or subsequent years of the university life.

When the academicians were asked whether school experience and teaching guidebooks were specific to the field, it was found that no universities had guidebooks specifically prepared for the field of Social Sciences Teaching. When the guidebooks used were examined, it was found that 7 universities stated that they used MNE decree law as guide, while 7 universities pointed out that they used the CHE/World Bank guidebook dated 1998 as guide. The other universities, on the other hand, stated that they followed the two guidebooks or used them after a revision. In parallel with the findings of the present study, Hacioğlu \& Aklan (1997)'s study argued that the use of guidebooks prepared on the basis of common grounds without heed to fields of specialty could lead to some problems and demanded that guides should be prepared in a way that would enable raising of teachers in line with professional standards. Moreover, when it was examined whether the duties and responsibilities of the stakeholders had been specified in the school experience and teaching practice guidebooks, it was seen that the guides of 10 universities specified the duties and responsibilities of the stakeholders separately, whereas 7 of the guidebooks did not do so. In parallel with the finding of the study, Şahin (2003)'s study pointed out that the duties and responsibilities of the stakeholders should be stated clearly.

In light of the results obtained from the study, it can be argued that in general education faculties are in need of up-to-date internship guidebooks and that these guidebooks should be prepared in a manner that it will be fieldspecific and have appropriate directives and examples. The language of the guidebooks to be prepared should be clear and intelligible, and they should contain weekly directives, specify the duties and responsibilities of the stakeholders and be prepared in a way that they will help teachers, academicians and pre-service teachers to meet on a common ground. It is also suggested that the number of pre-service teachers per mentor and academician 
should be reduced to a more reasonable figure. Moreover, appointment of advisers should be done on a voluntary basis on the part of teachers and academicians so that the training to be received by pre-service teachers will be more appropriate and beneficial. It can also be suggested that in the current system, seminars should be organized in cooperation with MNE and CHE in order for mentors to be better mentors for pre-service teachers and handbooks and brochures should be distributed to them.

\section{References:}

1. Abazaoğlu, İ., Yildırım, O. \& Y1ldızhan, Y. (2014). Turkey's teacher profile. Turkish Studies, 9(2), 1-20.

2. Abazoğlu, İ., Yıldırım, O. \& Y1ldızhan, Y. (2016). Teacher training in turkish educational system from past to present. International Journal of Turkish Education Sciences, 4 (6), 143-160.

3. Aglazor, G. (2017). The role of teaching practice in teacher education programmes: designing framework for best practice. Global Journal of Educational Research, 16, 101-110.

4. Akdemir, A. S. (2013). A history of teacher training programmes and their problems in turkey. Turkish Studies, 8 (12), 15-28.

5. Akyüz, Y. (2001). Başlanglçtan 2001'e - Türk eğitim tarihi. İstanbul: ALFA.

6. Alemdağ, E. \& Özdemir Şimşek, P. (2017). Pre-Service teachers' evaluation of their mentor teachers, school experiences, and theorypractice relationship. International Journal of Progressive Education, 13 (2), 165-179.

7. Allen, J. M. \& Wright, S. E. (2014). Integrating theory and practice in the pre-service teacher education practicum. Teachers and Teaching, 20(2), 136-151.

8. Assimonye, A. C. (2014). Teaching practice policy for NCE teacher education programme: a critique. Knowledge Review, 31(2), 1-4.

9. Atanur Başkan, G., Aydın, A. \& Madden, T. (2006). Türkiye'deki öğretmen yetiştirme sistemine karşılaştırmalı bir bakış. Ç. Ü. Sosyal Bilimler Enstitüsü Dergisi, 1 (1), 35-42.

10. Aytaçl1, B. (2012). Evaluation of school experience and teaching practice courses in undergraduate programme of elementary mathematics education. Unpublished MA Thesis, Ege University, İzmir, Turkey.

11. Baştürk, S. (2009). Investigating teaching practice course according to student teachers' opinions. Elementary Education Online, 8(2), 439456.

12. Büyükduman, İ. (n.d.). Türkiye'de öğretmen yetiştirme. Retrieved February 12 , 2020, from 
https://www.academia.edu/4120789/Türkiyede_Öğretmen_Yetiştirm e

13. Cain, T. (2009) Mentoring trainee teachers: how can mentors use research? Mentoring \&Tutoring: Partnership in Learning, 17 (1), 5366.

14. Carpenter, L. \& Balence, B. (2007). Teaching internships and the learning community. Retrieved February 13, 2020, from https://www.researchgate.net/publication/

29466834_Teaching_Internships_and_the_Learning_Community

15. Clarke, A., Triggs, V. \& Nielsen, W. (2014). Cooperating teacher participation in teacher education a review of the literature. Review of Educational Research, 84(2), 163-202.

16. Cresswell, J. W. (2018). Nitel Araştırma Yöntemleri: Beş Yaklaşıma Göre Nitel Araştırma Ve Araştırma Deseni (Qualitative Inquiry and Research Design: Choosing Among Five Approaches) (4 ${ }^{\text {th }}$ Ed.). (Trans. Edt.: Mesut Bütün and Selçuk Beşir Demir). Ankara: Siyasal

17. Çelik, M. (2008). Pre-service EFL teachers' reported concerns and stress for practicum in Turkey. Education and Science, 33(150), 97109.

18. Çelikkaya, T. (2011). Expectations of preservice social studies teachers from the lesson of teaching practice and fulfilment levels of these expectations. International Social Science Education of Journal - ISSE, 1(2), 155-172.

19. Ekizer, D. (2006). Mentoring primary school student teachers in Turkey: seeing it from the perspectives of student teachers and mentors. International Education Journal, 7 (7), 924-934.

20. Ekpo, O. J. (2019). Internship for student-teachers. Retrieved February 12, 2020, from https://www.researchgate.net/publication/334260464_INTERNSHIP _FOR_STUDENT-TEACHERS

21. Ergüneş, Y. (2005). Evaluating whether school experience course activities are done by students in accordance with the course objectives. Balıkesir Üniversitesi Sosyal Bilimler Enstitüsü Dergisi, 8 (13), 106-128. Retrieved February 12, 2020, from https://dergipark.org.tr/en/pub/baunsobed/issue/50339/651857

22. Eryaman, M. Y. (2007). From reflective practice to practical wisdom: Toward a post-foundational teacher education. International Journal of Progressive Education, 3(1), 87-107.

23. Göktaş, Ö. \& Şad, S. N. (2014). Assigning the practice teachers for school experience and teaching practice courses: criteria, challenges and suggestions. H. U. Journal of Education, 29(4), 115-128. 
24. Görgen, İ., Çokçalışkan, H. \& Korkut, Ü. (2012). The functionality of the practicum course in terms of teacher candidates, mentors, and practice lecturers. Muğla Üniversitesi Sosyal Bilimler Enstitüsü Dergisi, 28, 56- 72.

25. Güngör, İ. C. (2018). Views about the follow-up period and assessment method of school experience and teaching practice courses in social studies education. Unpublished MA Thesis, Ondokuz Mayis University, Samsun, Turkey.

26. Hacıŏglu,F. \& Alkan C. (1995). Öğretmenlik Uygulamaları Öğretim Teknolojisi. Ankara: Alkım.

27. Hobson, A. J. (2002). Student teachers' perceptions of schoolbased mentoring in initial teacher training (ITT). Mentoring \& Tutoring, 10 (1), 5-19.

28. Hudson, P. (2013) Mentoring as professional development: 'growth for both' mentor and mentee, Professional Development in Education, 39 (5), 771-783.

29. Hurioğlu, L. (2016). The effect of feedback on pre-service teachers' teaching practice and lesson plan preparing skills along with selfefficacy levels during the process of teaching experience. Unpublished PhD Thesis. Çukurova University, Adana, Turkey.

30. Izadinia, M. (2016) Student teachers' and mentor teachers' perceptions and expectations of a mentoring relationship: do they match or clash? Professional Development in Education, 42 (3), 387402.

31. Jones, M. (2001) Mentors' perceptions of their roles in school-based teacher training in England and Germany. Journal of Education for Teaching, 27 (1), 75-94.

32. Kazmer, M. M. \& Xie, B. (2008). Qualitative interviewing in internet studies playing with the media, playing with the method. Information, Communication \& Society, 11 (2), 257-278.

33. Kessels, J. P. A. M. \& Korthagen, F. A. J. (1996). The relationship between theory and practice: back to the classics. Educational Researcher, 25(3), 17-22.

34. Kilıç, D. (2004). The evaluation of the effects of the teaching practice courses on teacher candidates. Kazım Karabekir Eğitim Fakültesi Dergisi, 10,172-184.

35. Maynard, T. (2000). Learning to teach or learning to manage mentors? experiences of school-based teacher training. Mentoring \& Tutoring: Partnership in Learning, 8(1), 17-30.

36. Meho, I. L. (2006). E-mail interviewing in qualitative research: a methodological discussion. Journal of the American Society for Information Science and Technology, 57(10), 1284-1295. 
37. Merriam, S. B. (2018). Nitel Araştırma/ Desen ve Uygulama Için Bir Rehber. (3 ${ }^{\text {rd }}$ Ed.).(Trans. Edt. Selahattin Turan). Ankara: Nobel.

38. Miles, M.B. \&Huberman, A.M. (1994). Qualitative data analysis: an expanded source book. (2nd ed). Thousand Oaks, CA: Sage.

39. MNE (2018). Uygulama öğrencilerinin millî eğitim bakanlığına bağlı eğitim öğretim kurumlarında yapacakları öğretmenlik uygulamasına ilişkin yönerge. Retrieved February 12, 2020, from http://oygm.meb.gov.tr/meb_iys_dosyalar/2018_06/25172143_YYne rge.pdf

40. Mtika, P. D. G. (2008). Teaching practice as a component of teacher education in Malawi: an activity theory perspective. $\mathrm{PhD}$ thesis, University of Nottingham.

41. Nonis, K. P. \& Jernice, T. S. Y. (2011). Beginner pre-service special education teachers' learning experience during practicum. International Journal of Special Education, 26 (2), 4-17.

42. Oğuz, S. \& Avc1, E. (2014). Views of social studies teacher candidates' about school experience course. Cumhuriyet International Journal of Education, 3 (3), 40-53.

43. Özkılıç, R., Bilgin, A. \& Kartal, H. (2008). Evaluation of teaching practice course according to opinions of teacher candidates. Elementary Education Online, 7(3), 726-737.

44. Paker, T. (2008). Problems of student teachers regarding the feedback of university supervisors and mentors during teaching practice. Pamukkale Üniversitesi Ĕ̈itim Fakültesi Dergisi, 1 (23), 132-139.

45. Riedler, M. \& Eryaman, M.Y. (2016). Complexity, diversity and ambiguity in teaching and teacher education: practical wisdom, pedagogical fitness and tact of teaching. International Journal of Progressive Education, 12(3), 172-188.

46. Saritaş, M. (2007). Evaluation of the opinions about the benefits of the application of experience to the teacher candidates. Uludağ Üniversitesi Eğitim Fakültesi Dergisi, 20 (1), 121-143.

47. Schwille, S. A. (2008). The professional practice of mentoring. American Journal of Education, 115 (1), 139-167

48. Seçer, Z., Çeliköz, N. \& Kayılı, G. (2010). Problems in school practices in department of pre-school teaching and solution offers. Yüzüncü Yll Üniversitesi Eğitim Fakültesi Dergisi, 7 (1), 128-152.

49. Sünkür Çakmak, M. (2019). Preservice teachers' opinions on teaching practice course. Journal of Social Sciences Institute, 13, 207-226.

50. Şahin E. (2003). Okulöncesi eğitimi öğretmenliği programında öğrenim gören öğretmen adayları ile uygulama okullarındaki öğretmenlerin mesleki uygulamalara ilişkin bakış açıları. Eğitim Araştırmaları Dergisi, 4(13). 
51. Şahin, E. ve Özkılıç, R. (2005). The opinions of preschool teacher candidates about the practice guide prepared for practice courses. Gazi Eğitim Fakültesi Dergisi, 25 (2),115-133.

52. Şişman, M. \& Acat, M. B. (2003). A study of school experiences practices and its effect on the perception of teaching profession. Firat University Journal of Social Science, 13 (1), 235-250.

53. Ünlü Saratl1, E. (2007). The qualification of mentoring serves that presented to the secondary school science student teachers during school experience- $i$ training. Unpublished MA Thesis, Gazi University, Ankara, Turkey.

54. Üstüner, M. (2004). Geçmişten günümüze türk eğitim sisteminde öğretmen yetiştirme ve günümüz sorunları. İnönü Üniversitesi Eğitim Fakültesi Dergisi. Retrieved February 12, 2020, from http://www.pegem.net/akademi/kongrebildiri_detay.aspx ?id=8232

55. Y1lmaz, G. (2019). The views of prospective teachers about feedback providing during teaching practicum. Unpublished MA Thesis, Gazi University, Ankara, Turkey.

56. Yılmaz, K. \& Kab, İ. (2013). Social studies teacher candidates' thoughts about and evaluations of 'school experience' and 'teaching practicum' courses. Humanitas, 1 (1), 197-215.

57. Yilmaz, M. (2011). The opinions of primary school teacher candidates about the teaching staff lecturing teaching practice course. Journal of Social Sciences, 10 (4), 1377-1387.

58. YÖK (1998). Eğitim fakülteleri öğretmen yetiştirme programlarının yeniden düzenlenmesi. Retrieved February 12, 2020, from https://www.yok.gov.tr/Documents/Yayinlar/ Yayinlarimiz/egitimfakultesi-ogretmen-yetistirme-lisans-programlari-mart-1998.pdf

59. Zeichner, K. (2002). Beyond traditional structures of student teaching. Teacher Education Quarterly,59-4. 